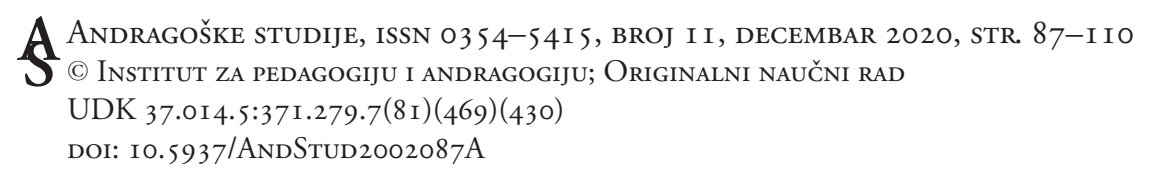

Natália Alves ${ }^{1}$

University of Lisbon, Portugal

Sabine Schmidt-Lauff ${ }^{2}$

Helmut Schmidt University, Germany

Catarina Doutor ${ }^{3}$

University of Lisbon, Portugal

Lucas Campos ${ }^{4}$

Federal University of Juiz de Fora, Brazil

\title{
Contexts of Recognition of Prior Learning: A Comparative Study of RPL Initiatives in Brazil, Portugal, and Germany
}

\begin{abstract}
The main purpose of this paper is to reflect on and compare the different 'realities' of Recognition of Prior Learning (RPL) regarding informal and non-formal learning contexts in three countries: Brazil, Portugal, and Germany. In Brazil, the Certific Network is a public policy that addresses the recognition and certification of prior learning. In Portugal, the Qualifica Programme is dedicated to the recognition of learnings and skills acquired throughout life. In Germany, the ProfilPass Project focuses on the values or skills acquired informally and non-formally. Regarding the international-comparative analysis methodology, the paper studies and compares these initiatives considering three comparative axes: 1) central aims, 2) target groups, 3) formats and structures of action. Such comparative research shows the importance of understanding RPL concepts and practical realities in different social, political and economic contexts.
\end{abstract}

Key words: recognition of prior learning, Brazil, Portugal, Germany.

\footnotetext{
${ }^{1}$ Natália Alves, PhD is Associate Professor at the Institute of Education, University of Lisbon, Portugal (nalves@ ie.ulisboa.pt).

${ }^{2}$ Sabine Schmidt-Lauff, PhD is Professor at the Helmut Schmidt University, Germany (schmidt-lauff@hsu-hh.de).

${ }^{3}$ Catarina Doutor, is a PhD candidate at the Institute of Education, University of Lisbon and an invited Assistant Professor at the University of Algarve, Portugal (catarinadoutor@edu.ulisboa.pt).

${ }^{4}$ Lucas Campos, is Assistant Professor at the Federal University of Juiz de Fora, Brazil and a PhD candidate at Rio de Janeiro State University in partnership with the Institute of Education, University of Lisbon, Portugal (lucas.pacheco@ufjf.br)
} 


\section{Introduction}

Over the last decades, recognition of prior learning (RPL) became one of the main topics of adult education policies in European Union (EU) countries and worldwide. The idea of recognising prior experiential learning is not new. However, different terms are used for RPL in different countries and international organisations (Guimarães \& Mikulec, 2020; Singh, 2015).

In the USA, the term in use is Prior Learning Assessment (PLA); in Canada, it is Prior Learning Assessment and Recognition (PLAR). In the UK, three different terms are used, each referring to different settings and aims: Accreditation of Prior Learning (APL) focuses on obtaining a higher education qualification; Accreditation of Prior Experiential Learning (APEL) concerns the assessment of competences and skills acquired through the work life; Accreditation of Prior Certificate Learning (APCL) consists of the assessment and certification of learning for academic proposes. The OECD uses the term Recognition of Non-Formal and Informal Learning (RNFIL); inside the EU, the recognition of prior learning is referred to as Validation of Non-Formal and Informal Learning (VNFIL) (Andersson, Fejes, \& Sandberg, 2013; Singh, 2015). In this article, we use RPL because it is the most common term in scientific journal articles.

The aim of this article is to compare three RPL policies: the Certific Network in Brazil, the Qualifica Programme in Portugal, and the ProfilPass Project in Germany. In order to develop an international-comparative analysis methodology (Bray \& Thomas, 1995; Egetenmeyer, 2012; Field et al., 2016), the article explores the following research questions: What are the central aims of these policies, considering the historical, political, and social context of each country? What are their target groups - individuals and social groups? What are their formats and structures of action - processes, networks, and instruments adopted for recognition of prior learning? In what follows, we briefly analyse the policy discourses on RPL, outline the methodological approach, describe the RPL programmes, and analyse them based on their similarities and differences.

\section{Discourses on Recognition of Prior Learning (RPL)}

The first practices of RPL occurred between the 1950s and the 1970s in the USA and Quebec (Canada). They shared a humanistic conception of education based on social and personal development, and their central motive was social justice. In both countries, RPL was developed to broaden access to higher education. With the end of the Second World War, US soldiers faced a labour market deeply 
changed by the massive entry of women into the labour force. The pursuit of studies, encouraged by the authorities, appeared as a chance to overcome the immediate difficulties of employment. However, war veterans refused to restart their studies at the point where they had interrupted them. They pressured governmental authorities and higher education institutions to recognise the knowledge acquired in the war in order to allow them access to higher education (Berger, 1991). According to Berger (1991), a similar situation took place in Quebec, but in this case, led by feminist movements. Feminists demanded the recognition of prior learning acquired through domestic activities to access higher education. The fact that these practices were aimed at very specific groups of the population neither allowed for great social visibility nor for their dissemination.

It was only in the 1990s and within the framework of the discourse on lifelong learning that RPL gained political importance and social notoriety, moving, as several academics state (see among other Guimarães \& Mikulec, 2020; Andersson, Fejes, \& Sandberg, 2013; Barros, 2013; Guimarães, 2012) from a focus on social justice to a focus on economic development and employability.

The White Paper on Education and Training (Commission of the European Communities [CEC], 1995) is a good example of an instrumental and managerial conception of education in general and RPL in particular. In this document, RPL plays a central role to solve the problem of young people without academic and professional qualifications and to promote workforce mobility within EU countries. After the adoption of the Lisbon Strategy in 2000 and the publication of the Memorandum on Lifelong Learning (CEC, 2001), RPL became a key instrument for achieving the knowledge-based society.

In subsequent years, a set of documents and guidelines were published: Common European principles for the identification and validation of non-formal and informal learning (Council of European Communities[CEC], 2004); European guidelines for validating non-formal and informal learning (CEDEFOP, 2015); Recommendations on the validation of non-formal and informal learning (CEU, 2012). These documents reveal both the importance attributed to RPL in the framework of European lifelong learning policy and the attempt to harmonise procedures within the European space. But they also disclose a paradox in policy discourses regarding RPL but also LLL. This paradox results from the inclusion of terms of the humanist discourse of the 1970s, which are now associated with policies focusing on human resources management and economic development. As Andersson, Fejes, and Sandberg (2013) put it, 'Despite borrowing elements from previous discourse, the aforementioned is a quite different discourse from the humanistic one from the 1970s. The current discourse aims 
at shaping citizens who want to learn and who take responsibility for their own learning in order to become employable' (p. 407).

\section{Methodology}

Taking into account the complexities of comparative research/methodology in the field of adult education, this article concentrates on adult education, focusing on issues and contexts related to RPL in three different countries: Brazil, Portugal, and Germany. As mentioned before, the aim of this comparative study is to present RPL programmes - Certific Network, Qualifica Programme, and ProfilPass Project-and to analyse the differences and the similarities among them according to: 1) their central aims, considering the historical, political, and social context of each country; 2) their target groups - individuals and social groups; and 3) their formats and structures of action - processes, networks, and instruments adopted for recognition and certification.

According to Egetenmeyer (2016), 'comparative adult education can be understood as a specific perspective in adult education research (rather than a method or a research field in its own right), one that stresses interrelations and contexts of comparison' (p. 80). Following this approach, we think that RPL, as an important issue in adult education, can be compared between different contexts and countries. By developing comparative research in adult education, this article argues for the need to compare adult education programmes in different contexts.

In fact, comparative education offers, according to Jean-Francois (2020), 'a wide range of opportunities for culturally contextualized analyses of countryspecific characteristics of education systems and adult education' (p. 41). For Egetenmeyer (2012), the comparison can involve four steps: 1) descriptive juxtaposition; 2) analytical juxtaposition; 3) descriptive comparison; and finally, 4) analytical comparison. In this sense, it is important to have 'comparable categories (what) but also comparable contexts (where, when and which)'; therefore, 'testing categories and contexts in juxtaposition is a starting point for comparative research in adult education' (Egetenmeyer, 2016, p. 94). Then, the next step is interrelating the data to interpret similarities and differences. As pointed out by Charles and Hilton (cited in Slowey, 2016) 'the real value of comparative study emerges only from stage three - the attempt to understand why the differences and similarities occur and what their significance is for adult education and the countries under examination and in other countries where the finding of the study may have relevance' (pp. 9-10). There is no doubt, therefore, that compar- 
ative research helps to understand and to interpret the differences and similarities between countries. Having said this, a comparison allows us to analyse individual cases, find similarities and differences and, in the end, search for justifications. The discussion in this article is based on a document analysis of official policy documents, legal regulations, reports, and policy documents produced by national and international organisations and scientific articles about RPL in Brazil, Portugal, and Germany.

\section{RPL in Three Countries: Brazil, Portugal, and Germany}

The following section offers a comparative analysis of RPL in three countries: Brazil, Portugal, and Germany.

\section{Brazil: the Certific Network}

This part of the paper presents the Certific Network, which is considered an exemplary case of RPL in Brazil. First of all, it is important to highlight that there isn't a tradition of permanent or long-term RPL policies in the country. There are some government initiatives, developed mainly in recent years, which aim to stimulate the recognition of learning acquired throughout life for specific social sectors and certain professional categories.

Among such initiatives, the most relevant - which comes closer to a structural and permanent RPL programme - is the 'National Network of Professional Certification and Initial and Continuing Training', in short Certific Network. It is a public policy for professional education focused on what the Brazilian government calls 'social inclusion'. It focuses on low-skilled workers, who seek the certification of professional knowledge obtained through processes of non-formal and informal learning 5 .

Despite being provided in the guidelines issued by the National Law of Education Directives and Base Lines (Law No. 9.394/1996), it was not until

\footnotetext{
5 We use the definition developed by Harris and Wihak (2014, p.13): 'Formal learning is structured and intentional, achieved through programmes/courses at accredited educational institutions (e.g. certificate, diploma or degree) and/or recognised by a regulatory body/professional organisation for certification. Non-formal learning is also intentional, gained through participation in organised workplace-based training, noncredit courses and workshops, but does not generate formal credit. Informal learning is incidental learning from life experience, workplace-based tasks, volunteer activities, and/or self-directed learning and study.' To transform informal learning processes into recognised ones instead of something which just happens ('the whole life is a learning journey'), some of the RPL concepts like the ProfilPass in Germany bring incidental learning into reflective recognition. This means to first see and then understand where learning happened. It is like formalising the informal by becoming aware of it.
} 
November 2009 that the Certific Network was actually regulated and created through Interministerial Ordinance No. 1.082. The delay in this creation, which was only possible due to a long series of demands and pressures made by education professionals, researchers, and civil society organizations, highlights the fact that there is little tradition in Brazil when it comes to RPL. In fact, it was only in the last 15 years that most of the few RPL initiatives that exist nowadays have emerged.

The Certific Network bases its recognition process on the concept of professional certification, which presents itself as something that transcends reductionist notions of merely educational or occupational certification. The pillars of this perspective of professional certification were based on the French policy of acquired experiences validation and on the Portuguese programme of recognition of school and work knowledge, seeking an articulation of these experiences considering the specific aspects and needs of Brazilian reality.

In fact, Brazilian economic, political, and social reality must be brought to attention in any reflection and/or practice that is inspired by foreign experiences, especially those developed in advanced capitalist economies, such as the United States or European countries.

As highlighted by the "Guiding Document" of the Certific Network, created and published in 2014, it is important to consider the specifications of the labour context in Brazil. These include: low education level of the labour force (especially among professions linked to manual and rural activities); deep presence of informal and illegal labour (child labour and slavery-like labour are also an issue); maintenance of fordist or hyperfordist production regimes in the present context of neoliberal globalisation; the impact of the dimensions of race, ethnicity, and gender in the integration into the labour market, which means extremely high inequalities between men, women, white, black and indigenous people, etc.; public education, social security, and employment systems which are still far from satisfying the needs of the population (despite the visible advances made especially since the 1988 Constitution); persistent existence of misery and hunger in several regions and large sectors of the population.

Thus, taking some foreign examples as an inspiration, but seeking to consider the national reality, the supporting pillars of the Certific Network actions may be summarised in the following axes: 1) Social recognition of knowledge built throughout life, linked to a profession; 2) Continuity of studies in professional education; 3) Increase in educational levels; 4) Articulation with the Public Employment System (Certific Network, 2014).

The policy targets young and adult workers, over 18 years old, who fit the following requirements: 'holders of a certificate or diploma compatible with the 
minimum education required for the respective professional certification process'; 'inserted or not in the labour market'; interested in 'formal recognition of professional knowledge, skills and competences developed in formal and nonformal learning processes and in their life and work trajectory' (Certific Network, 2014, p. 26). The Network is configured as

[...] a set of actions that aim to establish professional certification processes to assist young and adult workers who seek for formal recognition and certification of professional knowledge, skills and competences, for the purpose of further studies and/or professional practice. (Certific Network, 2014, p. 26.)

Therefore, its central aims are:

I - offer professional certification processes free of charge for purposes of study or professional practice;

II - monitor and evaluate the implementation of professional certification processes; and

III - articulate public policies on employment, work and income, professional training and schooling, through strategies that aim for social inclusion and equity in the creation and construction of educational projects for professional certification. (Certific Network, 2014, p. 26)

It is based on these pillars and aims that the Certific Network was implemented in 2009 as a state strategy that includes a large set of governmental and non-governmental sectors and organisations. Such large dimensions can be observed since the beginning of the policy, which is planned, organised and developed by the Ministries of Education and Labour ${ }^{6}$.

Its governance structure is composed of three levels (national level; institutions and networks level; educational units level), which have their own deliberative and operational organisations (such as the 'National Committee for Professional Education Policies' at the national level; the 'Deliberative Chambers' at the institutions and networks level; and the 'Councils' at the educational units level).

Although the organisations that compose the national level have strategic responsibilities (build, approve, and disseminate rules; monitor activities, etc.), it is at the other two levels that the concrete actions in professional certification are

\footnotetext{
${ }^{6}$ It is important to note that since 2016, just after the impeachment of ex-president Dilma Rousseff, the Ministry of Labour has seen too many modifications and reductions. In 2019, under Jair Bolsonaro's government, it was eliminated. Its responsibilities were distributed among the Ministries of Economy, Citizenship, and Justice. The impacts of this profound restructuring can already be seen at several levels, such as the weakening of Labour Justice and growing difficulties to access labour rights. It is a task for the future to investigate what this may mean for the Certific Network.
} 
developed, such as creating certification processes and training qualified professionals to act in them (institutions and networks level); create procedures for the development, monitoring and evaluation of professional certification processes (educational units level).

In addition to the strategic core, the Network includes other entities that assume responsibilities related to 'education, certification, metrics, standardization and professional use' (Certific Network, 2014, p. 22). They are public institutions that encompass the federal, provincial, district, and municipal networks of vocational education, the national learning services, and non-governmental organisations.

It is necessary to highlight that the Certific Network was created in the midst of a series of initiatives by the Brazilian government that had the ultimate goal of reorganising and expanding federal institutions focused on basic and vocational education. In this context, the Certific Network was organised according to the structure of the 'Federal System of Professional, Scientific and Technological Education', a public system which connects vocational and college education. It is composed of 64 institutions, located in all regions and states of the federation, with 661 units currently in operation. This system is very important for the Certific Network. For example, the Certific Centres (the units that effectively develop the certification processes) operate through the existing structure of the 'Federal Network of Professional, Scientific and Technological Education'.

However, it is very difficult to measure and confirm the success of this RPL policy. Despite the wide system of governance and operational organisations, until 2015, throughout the country, only 25 units offered recognition and certification programmes, linked to only five professional areas (aquaculture; music; civil construction; electronics; tourism) (Costa, 2015). Besides that, there is unclear information about the number of Certific Centres currently in operation and the number of workers who benefited from the Certific Network.

According to Costa (2015), there are no extra funds for physical structure or even for hiring professionals for the Certific Network. This means that there is no allocation of financial resources to the certification units. The used resources (physical structure and labour force) are those that already exist in the institutions (ex: the regular budget and teachers of the 'Federal System of Professional, Scientific and Technological Education'), which had started to develop one more task (in addition to all the previously existing demands): the RPL process. This situation has 'hampered, delayed or prevented the policy from being implemented' (Costa, 2015, p. 110). 


\section{Portugal: the Qualifica Programme}

In Portugal, the evolution of adult education was connected to the Democratic Revolution in 1974. Due to policy discontinuities, adult education only became a political priority in the 1990s as a result of supranational influence from the EU on the national educational agenda ${ }^{7}$. In the last two decades, adult education in Portugal was characterised by strong political intermittencies. In fact, several initiatives and programmes, such as New Opportunities, have been implemented in order to respond to the need for improving the qualification of the Portuguese population. However, these initiatives were not successful; the country continues to face a structural problem of low educational attainment. Among Portugal's 10 million inhabitants, there are now 895,140 adults with no education level. In 2016, more than half of the population aged between 25 and 64 had not completed upper-secondary education. Only 33 per cent of the population aged 25-34 completed secondary education (OECD, 2018). Therefore, many adults have significant problems in basic skills (literacy, numeracy, and ICT) and, at the same time, face several obstacles in accessing the labour market.

Taking into account the structural deficit of the Portuguese population's qualification was necessary to develop the adult education and training programme. In March 2016, the newly elected government launched a new intervention called the Qualifica Programme, which aims to improve the levels of education and training of adults to help advance their education and employability. The programme was officially launched in March 2017 with a large-scale public awareness campaign titled 'More qualification, a better job!'. The strategic priority of Qualifica is to improve adult qualification and, at the same time, to promote lifelong learning (Liebowitz, González, Hooge, \& Lima, 2018).

The main aims of the Qualifica programme are: 1) to increase adults' skills and qualification levels in order to improve employability of adults by providing them with skills valid for the labour market; 2) to reduce illiteracy rates and increase the participation rates of the population in education and training; 3) to improve the system with young adults investing more in education and training; 4) to bring educational attainment rates to the level of other European countries; 5) to adapt the offer and training networks to the needs of the labour market (Qualifica Programme, 2020). Another aim of the programme is '(...) to increase the number of specialised centres for adult education and training' (OECD, 2017, p. 47). According to Lima and Guimarães (2018), the Qualifica programme is expected to further coordination between the existing educational

7 The entry of Portugal in the European Economic Community (EEC) in 1986 enabled new opportunities because of financing programmes. In 1992, the EEC became the European Union (EU). 
provision, the labour market and regional, national and international economic development trends' (p. 617).

This form of provision has been attended by a large number of adults aged 18 years and over, unemployed people, youth not in employment, education or training (NEETs), or individuals wo did not complete basic or secondary education (OECD, 2017). This programme was designed for adults whose objective is to improve the populations' qualifications and employability.

What are the processes, networks, and instruments adopted for recognition and certification? The Qualifica Programme is supported by several actors, including the Ministry of Education and the Ministry of Labour, Solidarity and Social Security, which supervises the National Agency for Qualifications and Vocational Education and Training (ANQEP). ANQEP is the national public institution responsible for Qualifica Centres and, therefore, 'is an instrument of managing public offers targeted to adults' (Guimarães, 2020, p. 119).

The new public policy for adult education sector - Qualifica programmeis implemented in Qualifica Centres (through the publication of Ordinance No. 232/2016, of 29 August), which are promoted by public and private institutions, such as secondary schools, Institutes for Employment and Vocational Training, private companies, local associations and municipalities (Machado \& Barros, 2020). Qualifica has a network of 310 centres throughout the country. These centres are seen as important structures, because they provide adult-learning services, such as information, vocational guidance and support to adults about education and training opportunities (RPL, for example).

In this context, the centres' activities include attendance, counselling, guidance, and referral for learning pathways taking into account the qualification of adults. The pedagogical team includes coordinators, technicians of guidance, recognition and validation of skills, trainers or teachers, and administrative technicians. Funded by the European Social Fund (85\%) and with national resources $(15 \%)$, the Qualifica programme is free of charge for individuals.

The programme offers training pathways for low-qualified adults through adult education and training courses and the RPL process (Lima \& Guimarães, 2018). RPL ${ }^{8}$ intends to identify and recognise skills acquired by adults with low levels of education and qualification throughout their lifespan, in formal, informal and non-formal contexts (ANQEP, 2017a, 2017b). For that purpose, adults develop a portfolio about their life, demonstrating their interests, motivations, learnings, and

\footnotetext{
${ }^{8}$ To achieve the basic RPL level ( $6^{\text {th }}$ or $9^{\text {th }}$ grade), adults will have to demonstrate knowledge in the following standards: Language and Communication, Mathematics for Life, Citizenship and Employability, Information and Communication Technologies (ICT); the secondary level (12 $2^{\text {th }}$ grade) includes the following areas/ standards: Culture, Language and Communication, Society, Technology and Science; and Citizenship and Professionality. To earn professional RPL, adults will have to demonstrate technical knowledge in the profession that they propose/intend to certify.
} 
skills. To create this document, they have support from technicians and teachers/ trainers of the Qualifica Centre. In the RPL process, adults receive complementary training in areas with fewer skills for a minimum of 50 hours. After training, adults get a jury certification of competences, which takes into account the competences validated and certified in the process. The certification session is an important moment, because the adult is presented to a jury and, therefore, is evaluated by an exam. After the exam, the adult obtains partial or total certification.

The team of the Qualifica Centres is based on two important documents: Methodological Guide and Methodological Guideline 1 (ANQEP, 2017a, 2017b). The Methodological Guide refers to the procedures for RPL process, as well as professional qualification in Portugal. The second document, Methodological Guidance 1, identifies three moments for the final phase of the RPL: 1) preparation for the exam; 2) the Certification Jury (also called exam); and, finally, 3) evaluation and decision making (ANQEP, 2017b).

Based on a qualification strategy that involves educational and training responses and in order to achieve the aims outlined by the programme, the Qualifica Passport was created in 2017. This instrument is an important document that provides information on individuals' own educational and training record. Based on the adults' qualifications, it also directs them to important learning opportunities. As an electronic tool, the Qualifica Passport provides information to learners about their learning paths, helping them access further learning opportunities, thus putting in practice the flexibility of the credit system' (OECD, 2018, p. 75). This passport is very useful for Qualifica Centres and for adults, because it shows lifelong guidance and lifelong learning. Thus, when adults completed a training activity, a certificate is issue by the Information and Supply Management System (SIGO) and, therefore, registered in the Qualifica Passport.

Generally speaking, the Qualifica programme is a strategy to foster the training and qualification of the Portuguese population in order to improve people's employability and match their skills with labour market needs.

\section{Germany: the ProfilPASS Concept and Instrument}

The German concept ProfilPASS (PP) as an instrument for adults ${ }^{9}$ is based very much on the Lisbon Strategy, launched by the European Council, which identifies Lifelong Learning (LLL) as a priority of the European Union's education

\footnotetext{
9 There are other concepts such as earning credit for informal learning in higher education, e.g. APEL (Accreditation of Prior Experiential Learning) or PLAR (Prior Learning Assessment and Recognition). A second version of the ProfilPASS for young people was launched in 2007 for youth aged 13-14 and over; it is valid in schools at lower secondary level.
} 
policy. In 2001, the working document 'Memorandum on Lifelong Learning' (CEC, 2001) marked the start of the consultation process between the Commission and the Member States. Within the mega idea and political concept of lifelong and lifewide learning, proposals 'focus on the identification, assessment and recognition of non-formal and in-formal learning, and the transfer and mutual recognition of qualifications and diplomas' (CEC, 2001, p. 4). All documents that have appeared in the wake of the European communication process can be interpreted as affirmations of the concept of learning assessment, recognition and validation (Freitag, 2010). The developments guided by the Memorandum should be classified as a political mandate for the development of, firstly, the European Qualifications Framework for Lifelong Learning (EQF LLL ${ }^{10}$ ), followed by the development of RPL concepts and instruments.

From 2006 to 2012 the ProfilPASS ${ }^{11}$ was developed by a national consortium (German Institute for Adult Education - Leibniz Centre for Lifelong Learning (DIE), German Institute for International Educational Research (DIPF), and the Institute for Development Planning and Structural Research (IES) at the University of Hanover). Funding was provided by the Federal Ministry of Education and Research (BMBF) and the EU (ERASMUS+; Socrates):

The ProfilPASS is a German tool that assists people in finding out what their strengths and competences are. With the help of an advisor they discover their hidden competences and set their goals. Therefore, the ProfilPASS tool prevents people from dropping out of training and education.

The ProfilPASS system assumes that people acquire a large part of their competences in informal areas of life such as family, caring, voluntary work, and the like, which is of great importance. In Germany, there is no national strategy or regulation (law) for the recognition of prior learning. Therefore, 'users' are addressed instead of target groups:

Users are mostly people who are transitioning: job seekers, individuals keen to re-enter the labour market, immigrants, unqualified workers, people from marginalized groups, people who are endangered by unemployment, students transitioning from education to

\footnotetext{
${ }^{10}$ The EQF LLL 'is intended to act as a translation aid for learning outcomes in the form of learning assessments and as a "neutral instrument". The aim of the Qualification Framework is to create transparency, comparability and transferability of national educational qualifications. In essence, the EQF LLL is a matrix formed by eight levels to which descriptors for learning outcomes have been assigned. Learning outcomes are defined as "a combination of knowledge, skills and competence" which a "learner knows, understands and is able to do after completing a learning process".' (Freitag, 2010, pp. 9ff.).

${ }^{11}$ For a full overview see: https://www.profilpass-international.eu/files/pp_english.pdf.
} 
work or individuals who dropped out of education and training courses previously. In addition, entrepreneurs can use it to source employees. (Singh, 2016 ${ }^{12}$ )

The concept tries to balance, on the one hand, an economic notion, the need for employment and being employable, and labour market needs, and, on the other hand, individual interests and personal self-discovery. As the PP tool has it, "Working with the ProfilPASS is like a "timeout" from everyday routine. If you do decide to take the plunge, you will be embarking on a voyage of discovery destination: you. At its end, you will have come a lot closer to your own answers for "Where am I now?" and "Where am I going?"'13. The concept promotes a resource-oriented approach that contributes to a person's self-assurance.

Today, the ProfilPASS is a strong instrument that comprises 1) a tool, which provides 2) ProfilPASS service points (professional guidance) and assures 3) quality. More than 200,000 people have used ProfilPASS since 2006, of which half were adults $(74,000)$ and the other half young people $(89,000)$. Currently, 37 regional ProfilPASS- centres and more than 3500 PP counsellors in Germany support adults in the process of RPL. About 36 disseminators (Multiplikatoren) promote the ProfilPASS system in their region (Schrader \& Winther, 2016). So-called 'dialogue centres' have been established to train advisors in the methodology of documenting competences in a two-day preparatory seminar. The training of advisors is coordinated at the national level by the ProfilPASS Service Centre of the German Institute of Adult Education (DIE). More than 8,000 people are qualified counsellors, although not all of them offer counselling with the instrument.

The ProfilPASS emphasises self-exploration and self-reflection rather than an exact measurement of competences (competences comprise cognitive and motivational dimensions): certificates and qualifications are also mentioned. The various steps in the PP are:

1. Biographical interviews to stimulate users to narrate activities and episodes of successful performance.

2. Small-group discussions to highlight personal competences.

3. Self-assessment through performance of their identified competences.

4. Developing a vision for the future by combining users' own preferences and choices with the competences they themselves identify.

\footnotetext{
${ }^{12}$ For a condensed version see URL: https://uil.unesco.org/case-study/global-observatory-recognition-validation-and-accreditation-0/germany-rva-case-study.

${ }^{13}$ For a full overview and to understand the perspectives and different levels within the instrument, see the ProfilPASS handbook in six languages (German, English, French, Greek, Slovenian, and Spanish): https://www. profilpass-international.eu/index.php?article_id=141\&clang $=0$ and the method-carts https://www.profilpassinternational.eu/files/en-pp-methodcards.pdf.
} 
To expand the use and availability of PP and to adapt it to specific needs, several European projects have been launched, including 'CORE', which is designed to assess competencies for the re-integration of vulnerable and disadvantaged groups. 'COOCOU' is a project that builds on the ProfilPASS and addresses counsellors working with cognitively impaired people to bring forward their potential and interests for competence development. For this purpose, the ProfilPASS is adapted to the needs of cognitively impaired people, that is, in a barrier-free format. 'SCOUT' is a project that is linked to counsellors working with new immigrants. For this purpose, the ProfilPASS is adapted and translated into Simple Language.

During the start of the ProfilPASS in Germany, the ever-increasing number persons in low-skilled jobs, contractual and part-time work, were the top priority for RPL. It is felt, however, that further discussions are needed in relation to today's situation: the ubiquitous digitalisation of our societies, our experiences during COVID-19, and the transformations within and after (economic instability and short-time work, social instability, individual uncertainty). We need to reflect on the role and development of the recognition infrastructure; on guidance and counselling; assessment procedures; assessment standards; transparent and quality assured systems that support and complement the existing education system (Seidel, 2011). For example, it is not transparent who has already participated in the ProfilPASS and with what outcomes and benefits (individual, collective, and social level). How do professional adult educators and counsellors experience and evaluate this instrument? According to early studies, training providers are sometimes unable to adequately classify knowledge acquired through formal, non-formal and informal learning (cf. Bohlinger \& Münchhausen, 2011; Singh, 2016). 'They should be able to tailor courses on offer and teaching methods to reflect previous learning. Appropriate teaching methods should be developed to promote the intended informal learning so as to create at the same time a systematic link between different forms of learning.' (Singh, 2016, p. 126)

\section{Comparison and Interpretation}

After the short descriptive juxtaposition of RPL programs in Brazil, Portugal, and Germany, we intend, in this section, to present an analytical comparison between these programmes by highlighting some details of their similarities and differences and, consequently, some explanations. One first aspect is connected to the long (or not so long) tradition these countries have in the field of adult education.

Until 1974, adult education in Portugal was almost non-existent. After the Democratic Revolution, public policy adult education emerged from the negotia- 
tions between the state and civil society. Similar to Portugal, adult education in Germany became a central issue in the early 1970s. In fact, the state of Germany declared adult education to be an independent fourth sector of education in the 1970s (Nuissl \& Pehl, 2004). In Brazil, the subject of adult education ${ }^{14}$ as a specific area has been the topic of debates and initiatives at least since the 1940s (Di Pierro, Joia, \& Ribeiro, 2001; Almeida \& Corso, 2015). However, its trajectory was very unstable until the end of the $20^{\text {th }}$ century. The current understanding of adult education was defined only in 1996, with the 'National Law of Education Directives and Base Lines'. This long historical experience happened mainly because of pressure coming from civil society organisations, such as teachers' unions and literacy movements. Despite that, in Brazil, adult education continues to be a devalued object within the scope of laws, programmes, and the allocation of state resources (Rummert, 2007).

Another important similarity between Germany and Portugal is related to their entering the EU. While Germany became a member of the EU in 1958, Portugal's membership started in 1986. The EU entry of Germany and Portugal has enabled new opportunities thanks to financing programmes. Additionally, the influence of the European Union has been evident in the Portuguese educational agenda and in German education policy, especially after the Memorandum of Lifelong Learning.

Therefore, the EU performs an important role in adult education programmes such as strategies of lifelong learning in Portugal and Germany. The Qualifica Programme and the ProfilPASS concept and instrument were established in the context of lifelong learning policy. According to the Lisbon Strategy, it is important to improve the employability and qualification of workers. In this sense, Lima and Guimarães (2011) stress that the Lisbon Strategy had the purpose of 'constructing the most dynamic and competitive economy in the world by 2010 , based on knowledge and, simultaneously, capable of guaranteeing a sustainable economic growth, with more and better jobs and greater social cohesion' (p. 77). Thus, the fundamental aspects of the Lisbon Strategy focus on education, training, lifelong learning in articulation with labour and the knowledge society.

Following the influence of the EU, funding emerges as an important tool. Financing coming from structural funds (ESF) promotes several adult education programmes and activities directed to labour market needs. The Qualifica Programme and ProfilPASS were supported by EU structural funds and national funds. For example, Qualifica is funded by the ESF (85\%) and national resources (15\%). ProfilPASS is co-funded by the ERASMUS+ and/or Socrates Programmes

\footnotetext{
${ }^{14}$ In Brazil, adult education is known and treated as 'Youth and Adult Education'. The particularities regarding this theoretical conception will not be addressed in this paper, but it is important to note that they exist.
} 
of the EU, the German federal government and the state governments (Federal Ministry of Education).

On the other hand, Brazil is not an economically or socially developed nation. On the contrary, it is a Latin American country that had a late development inside the monopolist capitalist order of the $20^{\text {th }}$ century (Mandel, 1978). Also, it does not have the financial and political support of a supranational institution such as the EU. In this context, as Rummert (2007) states, the country has a persistent tradition of undervaluing adult education policies. In fact, it is a negative historical trend that affects all social policies, including adult education in particular. Therefore, it is not surprising that RPL policies have never received much attention from the different governments. The Certific Network is a great example of that. Despite being the most important RPL experience in the country, it does not have its own funding source. This is certainly one of the main causes of difficulties and delays in the implementation and operationalisation of this policy.

Concerning the historical, political, and social context, Certific is an innovative and recent policy that addresses RPL in Brazil. In fact, it was regulated and created in 2009 as a public policy for professional education focused on social inclusion. In Portugal, several initiatives and programmes have been implemented to increase the qualification of the Portuguese population; however, they were not successful. Qualifica was launched in 2017 with the same purpose.

Relating to public policy, the government seems to have an important role in these three programmes, namely in terms of guidance and support. Moreover, the state had an important role in adult education policy implementation through the intervention of central government entities - Ministry of Education and Labour (Certific), Ministry of Education and Ministry of Labour, Solidarity and Social Security (Qualifica), and Ministry of Education (ProfilPASS). Besides that, there are other national public institutions responsible for these programmes, such as Federal Institutes of Education (Certific), National Agency for Qualifications and Vocational Education and Training (Qualifica), and German Institute for Adult Education, German Institute for International Educational Research, and Institute for Development Planning and Structural Research (ProfilPASS). In the case of Brazil, the institutions involved in Certific are federal, provincial, district, and municipal networks of vocational education, the national learning services, and non-governmental organisations.

While Certific and Qualifica are public policies for adult education, the ProfilPASS is an instrument for adults. Certific and Qualifica are regulated, whereas ProfilPASS does not have regulation. According to Nuissl and Pehl (2004), AE 'is not regulated in the Constitution of the Federal Republic of Germany' (p. 19). 
Taking into account the low level of qualifications in Brazil and in Portugal, the Certific and the Qualifica are seen as political strategies. Both programmes are aimed to increase adult qualification. With the purpose of social inclusion, the Certific aims to assist workers who are interested in having their professional knowledge recognised and certified for the purpose of further studies or professional practice. This means that the knowledge that is acquired in nonformal and informal learning processes can be valued and certified - professional certification. Likewise, the Qualifica programme intends to increase adults' skills and qualifications level for the labour market. As a public provision, Qualifica's main aim is to improve the levels of education and training of adults to help advance their education and employability. In this vein, another aim of this programme is to adapt the offerings and training networks to the needs of the labour market. The aims of ProfilPASS are similar to those of Certific and Qualifica. It is designed to promote: 1) personal and professional (re)orientation; 2) (re)integration into professional life; 3) planning of professional evolution. These results show that employability seems to be an issue relevant to the adult education field. As Lima, Guimarães, and Touma (2016) point out:

[T] hese purposes arise in the context of globalisation and the restructuring of the Portuguese economy, also in keeping with the lifelong learning perspective established by the EU as part of human resources management principles, and with values related to social cohesion aimed at the integration of different participants in ALE, in line with the modernisation and social control and democratic and emancipatory models. (p. 51)

Nonetheless, these three programmes encompass an individual and reflexive approach, insofar as they want to help adults reflect on their experiences and learnings developed in non-formal and informal settings. Furthermore, this raises several issues related to individual self-esteem.

\section{Conclusion}

Recent statements about the multidimensional changes going on in our world (e.g. climate crisis, war, migration, and the COVID-19 pandemic) acknowledge lifelong learning, with an emphasis on adult education, 'as a human right - [it] must ensure the recognition, validation and accreditation of learning outcomes acquired in different contexts, democratizing the negotiation of individual and social learning demand' (UIL, 2020, p.10). To build an inclusive society, the recognition, validation, and accreditation (RVA) of prior learning is more important 
than ever for specific vulnerable and disadvantaged target groups (see Table 1). In this paper, we intended to compare similarities and differences between RPL initiatives in Brazil, Portugal, and Germany:

Table 1. Summary table with the main characteristics observed in the three cases (developed by the authors)

\begin{tabular}{|c|c|c|c|}
\hline $\begin{array}{c}\text { Analytical and } \\
\text { Comparison } \\
\text { Axes } \\
\end{array}$ & $\begin{array}{c}\text { Brazil } \\
\text { Certific Network }\end{array}$ & $\begin{array}{c}\text { Portugal } \\
\text { Qualifica Programme }\end{array}$ & $\begin{array}{c}\text { Germany } \\
\text { ProfilPASS Concept and } \\
\text { Instrument } \\
\end{array}$ \\
\hline \multirow[t]{3}{*}{ Context } & $\begin{array}{l}\text { I. Late capitalist } \\
\text { development, with low } \\
\text { education levels, deep } \\
\text { presence of informal } \\
\text { labour, high levels of } \\
\text { inequality, etc. }\end{array}$ & $\begin{array}{l}\text { I. Public policy for adult } \\
\text { education emerged after } \\
\text { the Democratic Revolution } \\
\text { in } 1974 \text {; }\end{array}$ & $\begin{array}{l}\text { I. EU Member State since } \\
1958 ; \\
\text { II. Adult education } \\
\text { became a central issue in } \\
\text { the early 1970s; }\end{array}$ \\
\hline & \multirow{2}{*}{$\begin{array}{l}\text { II. History of devaluation } \\
\text { in adult education and } \\
\text { low tradition in RPL } \\
\text { policies. }\end{array}$} & $\begin{array}{l}\text { II. EU Member State since } \\
\text { 1986, which has enabled } \\
\text { new opportunities through } \\
\text { financing programmes; }\end{array}$ & \multirow{2}{*}{$\begin{array}{l}\text { III. The state declared } \\
\text { adult education as an } \\
\text { independent fourth } \\
\text { sector of education in the } \\
1970 \text { s. }\end{array}$} \\
\hline & & $\begin{array}{l}\text { III. Evident influence of } \\
\text { EU on the Portuguese } \\
\text { educational agenda. }\end{array}$ & \\
\hline \multirow[t]{7}{*}{ Central Aims } & \multirow{2}{*}{$\begin{array}{l}\text { I. Offer professional } \\
\text { certification processes, } \\
\text { free of charge, for } \\
\text { purposes of study or } \\
\text { professional practice; }\end{array}$} & \multirow{2}{*}{$\begin{array}{l}\text { I. Increase adults' skills } \\
\text { and qualification levels } \\
\text { in order to improve the } \\
\text { employability of adults; }\end{array}$} & \multirow{3}{*}{$\begin{array}{l}\text { I. Increase adults' skills } \\
\text { and qualifications levels } \\
\text { for the labour market; } \\
\text { II. Assist people in } \\
\text { finding out their strengths } \\
\text { and competences; }\end{array}$} \\
\hline & & & \\
\hline & \multirow{2}{*}{$\begin{array}{l}\text { II. Monitor and evaluate } \\
\text { the implementation of } \\
\text { professional certification } \\
\text { processes; }\end{array}$} & $\begin{array}{l}\text { II. Reduce illiteracy } \\
\text { rates and increase the }\end{array}$ & \\
\hline & & $\begin{array}{l}\text { participation rates of the } \\
\text { population in education } \\
\text { and training; }\end{array}$ & \multirow{4}{*}{$\begin{array}{l}\text { III. Prevent people from } \\
\text { dropping out of training } \\
\text { and education. }\end{array}$} \\
\hline & \multirow{3}{*}{$\begin{array}{l}\text { III. Articulate public } \\
\text { policies on employment, } \\
\text { work and income, } \\
\text { professional training } \\
\text { and schooling, through } \\
\text { strategies that aim for } \\
\text { social inclusion and } \\
\text { equity in the creation and } \\
\text { building of educational } \\
\text { projects for professional } \\
\text { certification. }\end{array}$} & $\begin{array}{l}\text { III. Improve the system } \\
\text { with young adults investing } \\
\text { more in education and } \\
\text { training; }\end{array}$ & \\
\hline & & $\begin{array}{l}\text { IV. Bring educational } \\
\text { attainment rates to the } \\
\text { level of other European } \\
\text { countries; }\end{array}$ & \\
\hline & & $\begin{array}{l}\text { V. Adapt the offer and } \\
\text { training networks to the } \\
\text { needs of the labour market. }\end{array}$ & \\
\hline \multirow[t]{3}{*}{ Target Groups } & \multirow{3}{*}{$\begin{array}{l}\text { I. Young and adult } \\
\text { workers (over } 18 \text { years } \\
\text { old); } \\
\text { II. Holders of a certificate } \\
\text { or diploma compatible } \\
\text { with the minimum } \\
\text { education required for } \\
\text { the respective professional } \\
\text { certification process. }\end{array}$} & $\begin{array}{l}\text { I. Adults (over } 18 \text { years } \\
\text { old); }\end{array}$ & \multirow{2}{*}{$\begin{array}{l}\text { I. People who are } \\
\text { transitioning: job seekers, } \\
\text { immigrants, unqualified } \\
\text { workers, marginalized } \\
\text { groups, students } \\
\text { transitioning to work, etc; }\end{array}$} \\
\hline & & $\begin{array}{l}\text { II. Unemployed people and } \\
\text { youth not in employment, } \\
\text { education or training } \\
\text { (NEETs); }\end{array}$ & \\
\hline & & $\begin{array}{l}\text { III. Individuals without } \\
\text { completed basic or } \\
\text { secondary education. }\end{array}$ & $\begin{array}{l}\text { II. Entrepreneurs can use } \\
\text { the instrument to source } \\
\text { employees. }\end{array}$ \\
\hline
\end{tabular}




\begin{tabular}{|c|c|c|c|}
\hline $\begin{array}{l}\text { Analytical and } \\
\text { Comparison } \\
\text { Axes }\end{array}$ & $\begin{array}{c}\text { Brazil } \\
\text { Certific Network }\end{array}$ & $\begin{array}{c}\text { Portugal } \\
\text { Qualifica Programme }\end{array}$ & $\begin{array}{c}\text { Germany } \\
\text { ProfilPASS Concept and } \\
\text { Instrument }\end{array}$ \\
\hline $\begin{array}{l}\text { Format and } \\
\text { Structures }\end{array}$ & $\begin{array}{l}\text { I. Organised and } \\
\text { developed by the } \\
\text { Ministry of Education } \\
\text { and Ministry of Labour; } \\
\text { II. Governance and } \\
\text { operational structures } \\
\text { are composed of public } \\
\text { institutions of vocational } \\
\text { education networks } \\
\text { and non-governmental } \\
\text { organisations; } \\
\text { III. The most important } \\
\text { institution inside the } \\
\text { Network is the 'Federal } \\
\text { System of Professional, } \\
\text { Scientific and } \\
\text { Technological Education', } \\
\text { which contains the units } \\
\text { that effectively develop } \\
\text { the certification processes } \\
\text { (Certific Centres); } \\
\text { IV. Operationalisation } \\
\text { problems: there are no } \\
\text { extra funds for a specific } \\
\text { physical structure or } \\
\text { labour force. }\end{array}$ & $\begin{array}{l}\text { I. Organised and developed } \\
\text { by the Ministry of } \\
\text { Education and Ministry } \\
\text { of Labour, Solidarity and } \\
\text { Social Security; } \\
\text { II. Implemented in } \\
\text { Qualifica Centres, which } \\
\text { are promoted by public and } \\
\text { private institutions; } \\
\text { III. Supported by EU } \\
\text { structural funds and } \\
\text { national funds. }\end{array}$ & $\begin{array}{l}\text { I. An instrument } \\
\text { organised by the } \\
\text { Ministries of Education; } \\
\text { II. Not regulated by } \\
\text { the Constitution of the } \\
\text { Federal Republic of } \\
\text { Germany; } \\
\text { III. Supported by EU } \\
\text { structural funds and } \\
\text { national funds. }\end{array}$ \\
\hline
\end{tabular}

Although the countries compared here have invested in the financing of RPL, less attention has been given to the demand side, for example how companies and individuals can be encouraged to access RPL opportunities. So, what are the benefits of these RPL initiatives for learners or individuals? As Singh stated: 'From some countries we learn about difficulties in involving employers with RVA. These difficulties centre on a range of questions: Who will conduct RVA? Where will it be conducted? Who will pay for it? What actual benefits will it hold for employers? As well as the development of infrastructure and processes, aligning RVA to career and skills development (...).' (Singh, 2016, p. 144).

In general, it seems safe to say that the potential of RPL is not yet realised. One of the main topics might be furthering linkages between (adult) educational institutions working in the fields of RPL, labour market needs, workplaces, community life, and individual interests. (Critical) lessons learnt demonstrate the ongoing need for:

- $\quad$ high-level commitment by policymakers, institutional leaders, stakeholders and practitioners at the federal, provincial/territorial, and community levels (cf. Singh 2016); 
- tools and guidance as the currency of learning (instead of the learning outcome 'competencies');

- awareness-raising to highlight the benefits and opportunities of RPL to learners, employees, people not in education or employment, and employers (Singh, 2016);

- processes for RVA that facilitate access for underprivileged people who lack educational opportunities (Singh, 2016);

- processes that are trustworthy, reliable, and flexible, as well as rigorous in terms of $\mathrm{AE}$ professional expertise;

- the provision of transparent and openly accessible RPL information and support for learners (candidates);

- the presence of strong links between the education and training sectors, the world of work, and civil society (Singh 2016).

\section{References}

Almeida, A., \& Corso, A. (2015). A educação de jovens e adultos: aspectos históricos e sociais. In EDUCERE (Ed.), Anais do XII Congresso Nacional de Educação (pp. 1283-1299). Paraná: Pontifícia Universidade Católica do Paraná. Retrieved from https://educere.bruc.com.br/arquivo/pdf2015/22753_10167.pdf

Andersson, P., Fejes, A., \& SAndberg, F. (2013). Introducing research on recognition of prior

LEARNING. INTERNATIONAL JOURNAL OF LIFELONG EDUCATION, 32(4), 405-411.

ANQEP. (2017a). Orientação ao Longo da Vida nos Centros Qualifica - Guia Metodológico. Lisboa: ANQEP.

ANQEP. (2017b). Reconhecimento, Validação e Certificaçâao de Competências Escolares (RVCC Escolar) - Orientação Metodológica No1. Lisboa: ANQEP.

Barros, R. (2013). The Portuguese case of RPL new practices and new educators: Some tensions and ambivalences in the framework of new public policies. International Journal of Lifelong Education, 32(4), 430-446.

Berger, G. (1991). A experiência pessoal e profissional na certificaçáo de saberes: a pessoa ou a emergência de uma sociedade global. In Ministério da Educação (Ed.), Atas da Conferência Nacional Novos Rumos para o Ensino Tecnológico e Profissional (pp. 233-243). Porto: Gabinete de Educação Tecnológica Artística e Profissional (GETAP).

Bohlinger, S., \& Münchhausen, G. (2011). Validierung von Lernergebnissen-Recognition and validation of prior learning. Bonn: BIBB.

BraY, M., \& Thomas, R. M. (1995). Levels of comparison in educational studies: Different insights from different literatures and the value of multilevel analyses. Harvard Educational Review, 65(3), 472-490. 
CEDEFOP. (2015). European guidelines for validating non-formal and informal learning. Luxembourg: Office for Official Publications of the European Communities.

Certific Network. (2014). Guiding document. Brazil: Ministry of Education. Retrieved from http://portal.mec.gov.br/rede-certific

Commission of the European Communities [CEC]. (1995). White paper on education and training. Teaching and learning towards the learning society. Brussels: CEC.

Commission of the European Communities [CEC]. (2001). A memorandum on lifelong learning. Brussels: CEC.

Commission of the European Communities [CEC]. (2004). Common European principles for the identification and validation of non-formal and informal learning. Brussels: CEC.

CosTA, R. (2015). Rede CERTIFIC: percursos e percalços na formulação da política de reconhecimento e certificação de saberes dos trabalhadores (Doctoral dissertation). Porto Alegre: UFRGS.

Council of the European Union. (2012). Recommendations on the validation of nonformal and informal. Brussels: CEU.

Di Pierro, M., Joia, O., \& Ribeiro, V. (2001). Visôes da Educação de Jovens e Adultos no Brasil. Cadernos Cedes, 21(55), 58-77.

Egetenmeyer, R. (2012). Informal learning of managers in a multinational company in Germany, Great Britain and Spain: An intercultural comparison. In M. Bron Jr. \& J. Reischmann (Eds.), Proceedings of ISCAE Conference. Las Vegas (pp. 77-89). Las Vegas: ISCAE.

Egetenmeyer, R. (2016). What to compare? Comparative issues in adult education. In M. Slowey (Ed.), Comparative adult education and learning: Authors and texts (pp. 79-116). Firenze: Firenze University Press.

Field, J., KünZel, K., \& Schemmann, M. (2016). International comparative adult education research. Reflections on theory, methodology and future developments. Internationales Jahrbuch der Erwachsenenbildung. 39(1), 109-133.

Freitag, W. K. (2010). Recognition of prior learning. Working paper 208. Düsseldorf: Hans-Böckler-Stiftung.

Guimarâes, P., \& Mikulec, B. (2020). The paradox of utilitarian recognition of prior learning: The cases of Portugal and Slovenia. European Journal for Research on the Education and Learning of Adults, pre-published, 1-14.

GuimarâES, P. (2012). Critical links between recognition of prior learning, economic change and social justice. Journal of Adult and Continuing Education, 18(1), 61-76.

Guimarâes, P. (2020). Ressignificação da política pública de Educação de Adultos: que sentidos os Educadores de Adultos atribuem ao Reconhecimento, Validaçáo e Certificação de Competências nos Centros Qualifica? In R. Barros, P. G. Lima, \& M. Azevedo (Eds.), Rumos da educação e formação de adultos em Portugal e no Brasil: um balanço comparado de políticas e práticas (pp. 107-132). Brasil: Instituto Federal Rio Grande do Norte (IFRN). 
Harris, J., \& WiHAK, C. (2014). Introduction and overview of chapters. Handbook of the recognition of prior learning: Research onto practice. England and Wales: NIACE.

JeAN-Francois, E. (2020). Influence of comparative education on comparative adult education research and practice. Hessische Blätter für Volksbildung, 2, 41-54.

Law No. 9.394/i996, of 20 December of Presidency of Republic. National Law of Education Directives and Base Lines (2016). Retrieved from http://www. planalto.gov.br/ccivil_03/Leis/L9394.htm

Liebowitz, D., González, P., Hooge, E., \& Lima, G. (2018). OECD reviews of school resources: Portugal 2018. Paris: OECD.

Lima, L. C., \& Guimarấes, P. (2011). European strategies in lifelong learning. A critical introduction. Opladen \& Farmington Hills, MI: Barbara Budrich Publishers.

Lima, L. C., \& Guimarấes, P. (2018). Lógicas Políticas da Educação de Adultos em Portugal. Cadernos de Pesquisa, 48(168), 600-623.

Lima, L. C., Guimaráes, P., \& Touma, N. (2016). Adult learning and education policies in Germany, Portugal and Sweden: An analysis of national reports to CONFINTEA VI. In R. Egetenmeyer (Ed.), Adult education and lifelong learning in Europe and beyond. Comparative perspectives from the 2015 Würzburg Winter School (pp. 29-66). Frankfurt am Main: Peter Lang Edition.

Machado, M. M., \& Barros, R. (2020). Aspects of the historical construction of the identity of youth and adult education in Brazil and Portugal: Focus on the political agenda and its discursive practices. Cadernos de História da Educação, 19(1), 91-109.

Mandel, E. (1978). O Capitalismo Tardio. São Paulo, Brazil: Abril Cultural.

Nuissl, E., \& Pehl, K. (2004). Portrait continuing education Germany. Bielefeld: W. Bertelsmann Verlag.

OECD. (2017). OECD economic surveys: Portugal 2017. Paris: OECD Publishing.

OECD. (2018). Skills strategy implementation guidance for Portugal: Strengthening the adult-learning system. Paris: OECD Publishing.

Ordinance No. 232/20i6, of 29 August of Ministry of Education and Work, Solidarity and Social SECURITy (2016). Retrieved from https://dre.pt/application/file/a/75217575.

Rummert, S. (2007). A educação de jovens e adultos trabalhadores brasileiros no século XXI. O "novo" que reitera antiga destituição de direitos. Revista de Ciências da Educação, 2, 35-50.

Schrader, J., \& Winther, E. (2016). DIE Jahresbericht 2015. Bonn: DIE. Retrieved from https://www.die-bonn.de/docs/DIE_Jahresbericht_2015_weboptimiert.pdf

SeIdel, S. (2011). Anerkennung informell erworbener Kompetenzen in Deutschland: Vom Flickenteppich zum umfassenden System? In S. Bohlinger \& G. Münchhausen (Eds.), Validierung von Lernergebnissen - Recognition and validation of prior learning (pp. 349-368). Bonn: BIBB.

SingH, M. (2015). Global perspectives on recognising non-formal and informal learning. Why recognition matters. Hamburg: UNESCO Institute for Lifelong Learning. 
Singh, M. (2016). Germany RVA case study in education. The ProfilPASS System. Hamburg: UIL.

SLOwEY, M. (2016). Scoping the field of study: Key concepts in comparative adult education and learning. In M. Slowey (Ed.), Comparative adult education and learning: Authors and texts (pp. 1-42). Firenze: Firenze University Press.

UNESCO INSTITUTE FOR LIFELONG LEARNING (UIL). (2020). Embracing a culture of lifelong learning. Contribution to the Futures of Education Initiatives. Hamburg: UIL. 
Natália Alves ${ }^{15}$

Univerzitet u Lisabonu, Portugalija

Sabine Schmidt-Lauff ${ }^{16}$

Univerzitet Helmut Šmit, Nemačka

Catarina Doutor ${ }^{17}$

Univerzitet u Lisabonu, Portugalija

Lucas Campos ${ }^{18}$

Federalni univerzitet Žuiz de Fora, Brazil

\section{Konteksti priznavanja prethodnog učenja: komparativna studija inicijativa za priznavanje prethodnog učenja u Brazilu, Portugaliji i Nemačkoj}

Apstrakt: Glavna svrha ovog rada jeste razmatranje i upoređivanje različitih „stvarnosti“ u vezi sa priznavanjem prethodnog učenja u informalnim i neformalnim kontekstima učenja u tri zemlje, a to su Brazil, Portugalija i Nemačka. Javna politika "Certific Network“ u Brazilu uređuje priznavanje i sertifikaciju prethodnog učenja. Program „Qualifica Programme“ u Portugaliji posvećen je priznavanju znanja i veština koji se stiču tokom celog života. Projekat „ProfilPass Project“ u Nemačkoj usredsređen je na vrednosti ili veštine koje se stiču informalnim i neformalnim putem. Što se tiče metodologije međunarodne komparativne analize, u radu se te inicijative ispituju i upoređuju u tri komparativne ose: 1) ključni ciljevi, 2) ciljne grupe, 3) formati i strukture mera. Ovako sprovedeno komparativno istraživanje ukazuje na značaj razumevanja koncepata priznavanja prethodnog učenja i praktičnih stvarnosti u različitim društvenim, političkim i ekonomskim kontekstima.

Ključne reči: priznavanje prethodnog učenja, Brazil, Portugalija, Nemačka.

\footnotetext{
${ }^{15}$ Dr Natália Alves je vanredni profesor na Institutu za obrazovanje Univerziteta u Lisabonu, Portugalija (nalves@ie.ulisboa.pt).

${ }^{16}$ Dr Sabine Schmidt-Lauff je profesor na Univerzitetu Helmut Šmit, Nemačka (schmidt-lauff@hsu-hh.de).

${ }^{17}$ Catarina Doutor je doktorand na Institutu za obrazovanje Univerziteta u Lisabonu i gostujući vanredni profesor na Univerzitetu Algarve, Portugalija (catarinadoutor@edu.ulisboa.pt).

${ }^{18}$ Lucas Campos je vanredni profesor na Federalnom univerzitetu Žuiz de Fora, Brazil, i student doktorskih studija na Državnom univerzitetu Rio de Žaneira, Brazil, u saradnji sa Institutom za obrazovanje Univerziteta u Lisabonu, Portugalija (lucas.pacheco@ufjf.br).
} 